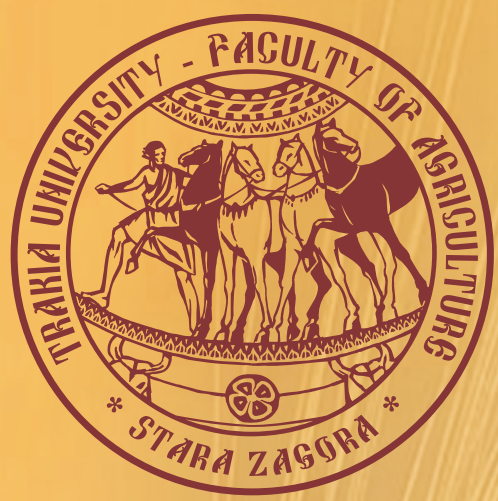

ISSN $1313-8820$ (print)

ISSN 1314 - 412X (online)

Volume 9 , Number 3

September 2017

\title{
AGRICULTURAL
}

\section{SCIENCE AND TECHNOLOGY}

\section{7}

An International Journal Published by Faculty of Agriculture, Trakia University, Stara Zagora, Bulgaria 


\section{Editor-in-Chief}

Georgi Petkov

Faculty of Agriculture

Trakia University, Stara Zagora

Bulgaria

E-mail: gpetkov@af.uni.sz.bg

\section{Co-Editor-in-Chief}

Dimitar Panayotov

Faculty of Agriculture

Trakia University, Stara Zagora

Bulgaria

\section{Editors and Sections}

\section{Genetics and Breeding}

Tsanko Yablanski (Bulgaria)

Atanas Atanasov (Bulgaria)

Svetlana Georgieva (Bulgaria)

Nikolay Tsenov (Bulgaria)

Max Rothschild (USA)

Ihsan Soysal (Turkey)

Horia Grosu (Romania)

Stoicho Metodiev (Bulgaria)

Bojin Bojinov (Bulgaria)

\section{Nutrition and Physiology}

Nikolai Todorov (Bulgaria)

Peter Surai (UK)

Ivan Varlyakov (Bulgaria)

George Zervas (Greece)

Vasil Pirgozliev (UK)

\section{Production Systems}

Radoslav Slavov (Bulgaria)

Dimitar Pavlov (Bulgaria)

Bogdan Szostak (Poland)

Banko Banev (Bulgaria)

Georgy Zhelyazkov (Bulgaria)

\section{Agriculture and Environment}

Martin Banov (Bulgaria)

Peter Cornish (Australia)

Vladislav Popov (Bulgaria)

Tarek Moussa (Egypt)

\section{Product Quality and Safety}

Stefan Denev (Bulgaria)

Vasil Atanasov (Bulgaria)

Roumiana Tsenkova (Japan)

\section{English Editor}

Yanka Ivanova (Bulgaria)
Scope and policy of the journal

Agricultural Science and Technology /AST/

- an International Scientific Journal of Agricultural and Technology Sciences is published in English in one volume of 4 issues per year, as a printed journal and in electronic form. The policy of the journal is to publish original papers, reviews and short communications covering the aspects of agriculture related with life sciences and modern technologies. It will offer opportunities to address the global needs relating to food and environment, health, exploit the technology to provide innovative products and sustainable development. Papers will be considered in aspects of both fundamental and applied science in the areas of Genetics and Breeding, Nutrition and Physiology, Production Systems, Agriculture and Environment and Product Quality and Safety. Other categories closely related to the above topics could be considered by the editors. The detailed information of the journal is available at the website. Proceedings of scientific meetings and conference reports will be considered for special issues.

\section{Submission of Manuscripts}

There are no submission / handling / publication charges.

All manuscripts written in English should be submitted as MS-Word file attachments via e-mail to editoffice@agriscitech.eu. Manuscripts must be prepared strictly in accordance with the detailed instructions for authors at the website

www.agriscitech.eu and the instructions on the last page of the journal. For each manuscript the signatures of all authors are needed confirming their consent to publish it and to nominate on author for correspondence.

They have to be presented by a submission letter signed by all authors. The form of the submission letter is available upon from request from the Technical Assistance or could be downloaded from the website of the journal. Manuscripts submitted to this journal are considered if they have submitted only to it, they have not been published already, nor are they under consideration for publication in press elsewhere. All manuscripts are subject to editorial review and the editors reserve the right to improve style and return the paper for rewriting to the authors, if necessary. The editorial board reserves rights to reject manuscripts based on priorities and space availability in the journal.

The journal is committed to respect high standards of ethics in the editing and reviewing process and malpractice statement. Commitments of authors related to authorship are also very important for a high standard of ethics and publishing. We follow closely the Committee on Publication Ethics (COPE), http://publicationethics.org/resources/guid elines

The articles appearing in this journal are indexed and abstracted in: DOI, EBSCO Publishing Inc., AGRIS (FAO) and DOAJ.

The journal is accepted to be indexed with the support of a project № BG051P00013.3.05-0001 "Science and business" financed by Operational Programme "Human Resources Development" of EU. The title has been suggested to be included in SCOPUS (Elsevier) and Electronic Journals Submission Form (Thomson Reuters).

The journal is freely available without charge to the user or his/her institution. Users can read, download, copy, distribute, print, search, or link to the full texts of the articles, or use them for any other lawful purpose, without asking prior permission from the publisher or the author.

This issue is printed with the financial support by Contract No DNP 0521/20.12.2016, financed from Fund 'Scientific Research' grant Bulgarian scientific Periodicals.

\section{Address of Editorial office:}

Agricultural Science and Technology Faculty of Agriculture, Trakia University

Student's campus, 6000 Stara Zagora

Bulgaria

Telephone: +35942699330 $+35942699446$

www.agriscitech.eu

Technical Assistance:

Nely Tsvetanova

Telephone: +359 42699446

E-mail:editoffice@agriscitech.eu 


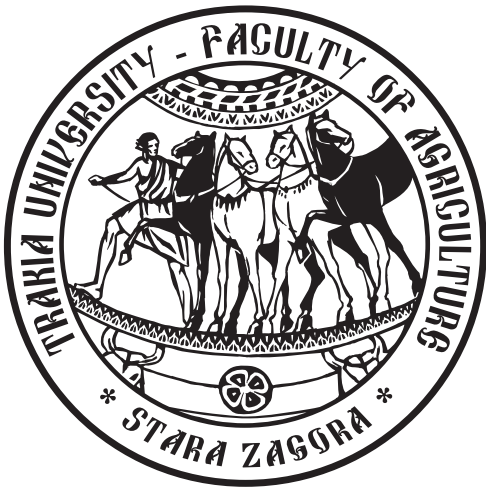

AGRICULTURAL

SCIENCE AND TECHNOLOGY

\section{7}

An International Journal Published by Faculty of Agriculture,

Trakia University, Stara Zagora, Bulgaria 


\title{
Achievements and problems in the weed control in grain sorghum (Sorghum Bicolor Moench.)
}

\author{
Gr. Delchev*, M. Georgiev \\ 'Department of Plant Production, Faculty of Agriculture, Trakia University, 6000 Stara Zagora, Bulgaria
}

(Manuscript received 28 November 2016; accepted for publication 21 March 2017)

\begin{abstract}
Chemical control has emerged as the most efficient method of weed control. Herbicides combinations and tank mixtures of herbicides with adjuvants, fertilizers, growth regulators, fungicides, insecticides are more effective than when applied alone on sorghum crops. Their combined use often leads to high synergistic effect on yield. The use of herbicide antidotes for the treatment of seeds in sorghum is a safe way to overcome its high sensitivity to many herbicides. Data regarding herbicide for chemical control of annual graminaceous weeds in sorghum crops are quite scarce even worldwide. Problem is the persistence of some herbicides used in the predecessors on succeeding crops, which is directly related to the weather conditions during their degradation. Most of the information on sorghum relates to the conventional technology for weed control. There is no information about the new Concep technology in grain sorghum. A serious problem is also the volunteers of the Clearfield and Express sun sunflower. They have resistance to herbicides different from that of conventional sunflower hybrids. There is no information yet in scientific literature on control of these volunteers.
\end{abstract}

Keywords: sorghum, herbicides, weeds control, grain yield, grain quality

\section{Introduction}

Weed infestation is the main limiting factor for the intensive farming of grain sorghum (Adu Tutu and Drennan, 1991; Rapparini, 1994; Rapparini et al., 1996; Limon-Ortega et al., 1998; Saayman, 2002). Problems of weed control in sorghum are being investigated by many authors (Rosa Santos, 1985; Perez, 1986; Rodríguez and Manzanilla, 1986; Walker et al., 1991; Covarelli et al., 1993; Tom and Courtney, 1993; Wicks et al., 1994; Rapparini et al., 1994; James et al., 1995, 1999; Onofri, 1996; Casas et al., 1997; Herrera and Oscar, 1998; Rapparini, 1999, 2001, 2002, 2003, 2004, 2005 and 2006; Arau et al., 2001; Michel, 2001; Borona et al., 2002; Archangelo et al., 2002; García, 2005; Tsuru et al., 2005).

\section{Weed control in sorghum crops}

According to Ramirez and Socorro (1998) in sorghum it is more cost-effective to proceed to minimum tillage and use of more herbicides.

According to Wicks et al. (1988 and 1994) the most appropriate herbicides for crop rotation winter wheat:grain sorghum are: 1) Use of pendimethalin in the autumn - after sowing before emergence, plus the application of 2.4-D in the spring - in tillering stage in winter wheat; 2) Treatment with glyphosate after harvest of the predecessor - in the stubble period, plus treatment of alachlor - after sowing before emergence of the sorghum grain. Alachlor control and wheat volunteer in sorghum crop. This herbicide combination can be used in both systems for crops with soil treatment without plowing, i.e. without inverting the soil layer.

Hormone similar herbicides Dicopur, DMA, Diolina, Habib, Sino and Jiad ensure very good control of broadleaf weeds during the growing season of sorghum and efficacy from 64 to $95 \%$. The grain yields of all herbicides are significantly higher than the grain yields obtained from the untreated check and comparable to that in weeded check (Bakheit and Omer, 2007; Abdel-Gadir et al., 2007,
2008).

Herbicides of dicamba base successfully control annual and perennial broadleaf weeds during the vegetation period of sorghum (Awad etal., 1991).

Volunteers of sorghum in soybean crops are controlled with imazethapyr, imazaquin, clomazone and sethoxydim (Defelice, 1990; Peixoto and de Souza, 2002). Volunteers of sorghum in maize crops are controlled with sulfonylurea herbicides, mainly primisulfuron and nicosulfuron (Rosales-Robles, 1993).

Kravtsov and Kotova (2006) after investigating the combinations of soil herbicides Trophy, Gezagard and Primextra with the foliar herbicide Agritox recommend as the most effective herbicide combination Gezagard + Agritox. Medrano et al. (1997) assessed the efficacy in weed control and selectivity in sorghum recommended herbicide Sempra (halosulfuron-methyl) only used in a mixture with the herbicide Barnes (acetochlor). Pohlan and Salazar (1994) reported high efficacy of herbicides MCPA, mecoprop, dichlorprop, pendimethalin and terbutilizan in sorghum. Hinz et al. (1997) investigating the metabolism of herbicides bentazone, nicosulfuron and primisulfuron in different maize and sorghum hybrids found that maize is tolerant to all three herbicide but sorghum is tolerant only to bentazone.

The main problem in sorghum is its high sensitivity to antigraminaceous herbicides, and therefore mechanical control of graminaceous weeds should be applied, but it increases the cost of production. It is necessary to review the current strategies for weed control in this crop (Bibard, 2004). For sorghum penetration of antigraminaceous herbicide in the plant is faster than in other cereal species - cultural and wild (Geminiani et al., 2006).

Sorghum helepense Pers. is the most dangerous graminaceous weed in the sorghum crop (Vecchiettini, 1997; Snyman, 1998). During the vegetation of sorghum it is impossible to control perennial graminaceous due to absence of selective herbicides for sorghum. The control of Cynodon dactylon Pers., Agropyrum repens L. and Sorghum helepense Pers. from rhizomes

* e-mail: delchevgd@dir.bg 
is done after yielding the predecessor during stubble period with total herbicides based on glyphosate. The most effective treatment is with them in the second half of June. The later application reduces herbicide efficacy. Addition of ammonium sulfate to glyphosate significantly increases the efficacy of the herbicide with treatments in July or August. Autumn treatments in September, with or without the addition of ammonium sulfate are less effective (Wicks, 1985; Brown etal., 1988).

\section{Sorghum productivity}

Many authors (Dean et al., 1990; Riechers et al., 1997; Castillo and Norma, 1998; Joaquin, 1998) reported data on protecting sorghum from antigraminaceous herbicides by using the herbicidal antidote fluxofenim (Concep III).

Mubarak et al. (2006) and Abdel-Gadir et al., (2009) investigated the efficacy and selectivity of the herbicide Dual Gold (S-metolachlor) introduced individually and as a tank mixture with the herbicide atrazine, with or without the antidote Concep III, for weed control in sorghum in the period after sowing before emergence. The authors reported that Dual Gold provides excellent control of annual graminaceous (95-100\%) and satisfactory control of annual broadleaf weeds $(50-66 \%)$. The addition of atrazine increased efficacy against broadleaved weeds at $90-97 \%$. When using Concep III seeds untreated with antidote, yields decreased by $20-38 \%$. When sowing seeds treated with Concep III no phytotoxic events are shown in sorghum hybrids, but yield is similar to that of the weeded check.

New herbicide Dual Gold contains mainly the isomer Smetolachlor. In the new herbicide Dual Gold the ratio of $S: R$ isomers was $90: 10$, while in the old herbicide Dual it was $50: 50$. S-isomer is about ten times more active than the R-isomer. The new ratio of the two isomers allows to significantly reduce the dose of the herbicide per unit area, and this leads to a reduced risk of phytotoxicity in sorghum (Roy et al., 2002).

To protect sorghum from the phytotoxic effect of metolachlor, alachlor, propachlor, primisulfuron by using herbicidal antidotes was reported by Fuerst and Gronwald (1986), Zama and Hatzios, (1986); Leif et al. (1987), Foy and Witt (1990), Wright et al. (1992), Simarmata and Penner (1993).

The use of a combination of pendimethalin and atrazine on sorghum was reported by Cruz (1991), a combination of metolachlor and atrazine was reported by Shakoor et al. (2000).

Wilkinson et al. (1990) found a connection between the sensitivity of some sorghum cultivars to metolachlor and their tolerance to manganese toxicity.

A total of 22 herbicide combinations based on pendimethalin, linuron, metolachlor, mesotrione, prosulfuron, 2.4-D, bentazone, dicamba, terbutilizan, isoxaflutole, bromoxynil, florasulam and pentoxamid are evaluated in relation to their effectiveness against weeds and phytotoxicity on sorghum plants (Vajs, et al. 2007). Sorghum hybrids of all variants are treated and not treated with herbicide antidote. Herbicide combinations, based on 2.4-D, pendimethalin, bentazone, dicamba, bromoxynil, pentoxamid and florasulam can be recommended for use in sorghum without herbicidal antidote, as they show high yields and low phytotoxicity. The herbicidal combinations based on linuron, isoxaflutole and mesotrione are highly phytotoxic to sorghum, and therefore they cannot be applied without specific antidotes. The herbicide combinations on the basis of metolachlor and terbutilizan can be used in sorghum also only with specific herbicidal antidotes, but a reduction of yield is possible from 5 to $10 \%$ in some years.
Sabatka et al. (1996) and Anderson et al. (1998) identify the biotypes of sorghum resistant to the herbicide primisulfuron. Their inclusion in the selection to create sorghum hybrids resistant to primisulfuron will significantly expand the spectrum of herbicides used with that crop.

According to some authors (Cobucci et al., 1998), sorghum is more sensitive to residues in soil of the herbicides imazamox, fomasafen and acifluorfen, compared with maize, millet and rice. According to others (Diawara and Banks, 1990), the use of herbicides 2.4-D, dicamba, metribuzin, oryzalin, fluochloridone or metolachlor in crop rotation sorghum:barley, does not affect the next crop. Along the same vein is the research by Unger (1994), according to whom the herbicides used in crop rotation sorghum:winter wheat do not have persistence in the rotation.

Jourdan et al. (1998) however found high sensitivity of sorghum residues of the herbicide imazethapyr in soil treated during vegetation of sunflower as predecessor. According to Dongiovanni et al. (2000) after the use of triasulfuron and metsulfuron in wheat as predecessor, the safe interval of sowing sorghum is 3 to 6 months depending on weather conditions.

\section{Quality characteristics of sorghum grain}

Studying hormone similar herbicides Diolina, Habib, Sino and Jiad applied during vegetation of sorghum, Abbas et al. (2008) found no residual amounts of the herbicide $2.4-\mathrm{D}$ in the grain of the investigated sorghum hybrids.

Herbicides atrazine and alachlor reduced primary root length and coleoptile length during the germination of sorghum. The herbicide 2.4-D did not affect the initial pace of development of the young plants (Rodella, 1991).

There is a decrease of seed germination during longer storage of seeds treated with herbicide antidotes flurazole and oxibetrinil. For this reason, the seeds should be stored without an antidote and must be treated immediately before sowing (Zhang et al., 1994).

\section{Conclusion}

Literature review shows that the views of the cited authors formulated a series of laws. Chemical control has emerged as the most efficient method of weed control. Herbicide combinations and tank mixtures of herbicides with adjuvants, fertilizers, growth regulators, fungicides, insecticides are more effective than when they are applied alone on sorghum crops. Their combined use often leads to high synergistic effect on yield. The use of herbicide antidotes for the treatment of seeds in sorghum is a safe way to overcome its high sensitivity to many herbicides.

Although without claim to offer an exhaustive literature review, it should be noted that the data regarding herbicides for chemical control of annual graminaceous weeds in sorghum crops are quite scarce even worldwide. A problem is the persistence of some herbicides used in the predecessors on succeeding crops, which is directly related to the weather conditions during their degradation.

Most of the information in sorghum relates to conventional technology for weed control. On some issues contrary opinions are published, due primarily to the different conditions under which the experiments were conducted and also the biological characteristics of the investigated cultivars and hybrids. There is no information about the new Concep technology in grain sorghum. Another serious problem are the volunteers of the Clearfield and Express sun 
sunflower. They have resistance to herbicides different from that of conventional sunflower hybrids. There is yet no information in scientific literature on the control of these volunteers.

\section{References}

Abbas IA, El-Habieb RY and El-Zorgani GA, 2008. Residues of Jiad 72 SL, Diolina 72 SL, Habib 72 SL and Sino 4 D 72 SL (2, 4-D) in sorghum. Proceedings: The $78^{\text {th }}$ meeting of the national pests and diseases committee, Wad Medani (Sudan), pp. 110-110.

Abdel-Gadir H, Dawoud DA, Abdel-Aziz E, Hamada AA and Babiker AG, 2009. Effects of dual gold 96\% EC (S-metolachlor) alone or in mixture with atrazine on preemergence weed control in sorghum. Sudan Journal of Agricultural Research, 14, 81-94.

Abdel-Gadir H, Dawoud DA and Hamada AA, 2008. Evaluation of the efficacy and selectivity of Jiad 72 SL, Diolina 72 SL, Habib 72 SL and Sino, 4 D 72 SL (new formulations of 2,4-D) for post-emergence weed control in sorghum. Conference Proceedings: The $78^{\text {th }}$ meeting of the national pests and diseases committee, Agricultural Research Corporation Conference, Wad Medani (Sudan), June 2008, pp. 62-69.

Abdel-Gadir H, Dawoud DA, Hamada AA and Osman AS, 2007. Evaluation of 2,4-D DMA 60SL (2,4-D) for post-emergence weed control in sorghum. Proceedings: The $76^{\text {th }}$ meeting of the pests and diseases committee, Wad Medani (Sudan), pp. 86-90.

Adu Tutu KO and Drennan DS, 1991. Effect of sulfonylurea herbicides on Striga. Proceedings of the $5^{\text {th }}$ international symposium of parasitic weeds, Ransom, J.K. Musselman, L.J. Worsham, A.D. Parker, C. (eds.), Nairobi (Kenya), pp. 361-371.

Anderson DD, Nissen SJ, Martin AR and Roeth FW, 1998. Mechanism of primisulfuron resistance in a shattercane (Sorghum bicolor) biotype. Weed science, 46, 158-162.

Arau IM, Valades-cerda MC, Maiti RK and Hernandez-Pinero JL, 2001. Variability among glossy and non-glossy sorghum genotypes in seedling and callus growth in response to 2,4-D treatments. Indian Journal of Plant Physiology, 6, 19-23.

Archangelo ER, Silva JB da, Silva AA da, Ferreira LR and Karam D, 2002. Forage sorghum tolerance to Primestra SC herbicide. Revista Brasileira de Milho e Sorgo, 1, 59-66.

Awad A, Worsham AD, Eplee R and Norris RS, 1991. Effects of dicamba, nitrogen and presowing hardening of host seed with phenolic acids on witchweed (Striga asiatica). Proceedings of the $5^{\text {th }}$ international symposium of parasitic weeds, Ransom, J.K. Musselman, L.J. Worsham, A.D. Parker, C. (eds.) Nairobi (Kenya), pp. 537-538.

Bakheit TN and Omer IE, 2007. Residues of 2,4-D (DMA) 60SL in sorghum. Proceedings: The $76^{\text {th }}$ meeting of the pests and diseases committee, Wad Medani (Sudan), pp. 91-92.

Bibard V, 2004. Weed control of sorghum crops: choose the right farming practices in order to facilitate chemical protection. Phytoma. La Défense des Végétaux. (no. 569) pp. 45-48.

Borona VP, Zadorozhnii VS and Karasevich VV, 2002. The use of herbicides on sorghum crops. Integrated system for plant protection. Present and future. Soroka, S., Supranovich, R., Bug, S., Trepashko, L., Zhukov, M., Timofeev, N. (ed.). Minsk (Belarus): pp. 32-34 (Ru).

Brown SM, Chandler JM and Morrison JE Jr, 1988. Glyphosate for johnsongrass (Sorghum halepense) control in no-till sorghum (Sorghum bicolor). Weed science, 36, 510-513.

Casas AM, Kononowicz AK, Zehr UB, Zhang LY, Haan TG,
Tomes DT, Bressan RA and Hasegawa PM, 1997. Approaches to the genetic transformation of sorghum. Proceedings of the $\mathrm{XV} \mathrm{II}^{\text {th }}$ conference on genetics, biotechnology and breeding of maize and sorghum held at Thessaloniki, Greece, Tsaftaris, A.S. (eds.), p. 8893.

Castillo C and Norma J, 1998. Fluzofenim protection activity (CONCEP III) applied in sorghum grain (Sorghum bicolor Moench), against the metalaclor action. Thesis for $\mathrm{PhD}$.

Cobucci T, Prates H, Falcao C and Rezende M, 1998. Effect of imazamox, fomesafen, and acifluorfen soil residue on rotational crops. Weed science, 46, 258-263.

Covarelli G, Onofri A and Marroni MG, 1993. Experimental researches on weed control of the sorghum. Informatore Agrario, 49, 67-72.

Cruz CR, 1991. Activacion de dos herbicidas y su incidencia en el control de caminadora (Rottboellia exaltata L.) en un cultivo de sorgo (Sorghum bicolor Moench) ubicado en un suelo de vega. Thesis for PhD.

Dean JV, Gronwald JW and Eberlein CV, 1990. Induction of glutathione S-transferase isozymes in sorghum by herbicide antidotes. Plant physiology, 92, 467-473.

Defelice MS, 1990. Shattercane (Sorghum bicolor) control in soybeans (Glycine max) with preplant and postemergence herbicides. Weed technology: a journal of the Weed Science Society ofAmerica, 4, 776-780.

Deibert EJ, 1989. Reduced tillage system influence on yield of sunflower hybrids. Agronomy journal, 81, 274-279.

Diawara MM and Banks PA, 1990. Weed control in barley (Hordeum vulgare) : no-till grain sorghum (Sorghum bicolor) production. Weed science, 38, 50-53.

Foy CL and Witt HL, 1990. Seed protectants safen sorghum (Sorghum bicolor) against chloroacetamide herbicide injury. Weed technology: a journal of the Weed Science Society of America, 4, 886-891.

Fuerst EP and Gronwald JW, 1986. Induction of rapid metabolism of metolachlor in sorghum (Sorghum bicolor) shoots by CGA-92194 and other antidotes. Weed science, 34, 354-361.

García R, 2005. Potencialidades de maíz, millo y girasol como cultivos alelopáticos para el control de malezas. Fitosanidad, 9, 2326.

Geminiani E, Bucchi R, Rapparini G, Romagnoli S and Vandini G, 2006. Uptake rapidity of fop and dim grass herbicides used in broadleaf crops [aryloxyphenoxypropionate; cyclohexenone; Sorghum bicolor Moench.; Setaria italica P. Beauv.; Lolium multiflorum Lam.; Avena sativa L.; Emilia-Romagna]. Atti delle Giornate Fitopatologiche, 1, 443-452.

Herrera D and Oscar M, 1998. Chemical control of weeds in sorghum (Sorghum bicolor Moench) in three application dates. Thessis for PhD.

Hinz JR, Owen MD and Barrett M, 1997. Nicosulfuron, primisulfuron, and bentazon hydroxylation by corn (Zea mays), woolly cupgrass (Eriochloa villosa) and shattercane (Sorghum bicolor) cytochrome P-450. Weed science, 45, 474-480.

James TK, Holland PT, Rahman A and Lu YR, 1999. Degradation of the sulfonylurea herbicides chlorsulfuron and triasulfuron in a high-organic-matter volcanic soil. Weed Research, Oxford, 39, 137147.

James TK, Klaffenbach P, Holland PT and Rahman A, 1995. Degradation of primisulfuron-methyl and metsulfuron-methyl in soil. Weed Research, 35, 113-120.

Joaquin TS, 1998. Protection activity of fluxofenim (Concep III) 
applied on sorghum grain (Sorghum bicolor Moench) against the action of metolaclor in two different environments. Thesis for PhD.

Jourdan SW, Majek BA and Ayeni AO, 1998. Soil persistence of imazethapyr and detection using a sensitive bioassay technique. Journal of Production Agriculture, 11, 52-56.

Kravtsov VA and Kotova NM, 2006. Influence of herbicides on yield and quality of green mass of sweet sorghum Parumben-4. Agroecology, 4, 70-74.

Leif JW, Burnside OC and Martin AR, 1987. Efficacy of CGA92194 and flurazole in protecting grain sorghum (Sorghum bicolor) from herbicide injury. Weed science, 35, 547-553.

Limon-Ortega A, Mason SC and Martin AR, 1998. Production practices improve grain sorghum and pearl millet competitiveness with weeds. Agronomy Journal, 90, 227-232.

Medrano C, Gutierrez W and Baez J, 13. 1997. Evaluacion de la eficacia en el control de malezas y la selectividad en el cultivo de sorgo (Sorghum bicolor Moench) del herbicida sempra (Halosulfuron metil) aplicado solo en mezcla con barness (acetocloro 90 C.E.). Agronomic Journeys, A. Romero, A. (Eds.), Maracay (Venezuela), pp. 69-70.

Mubarak HA, Dawoud DA, Abdel-Aaziz E, Babiker AT and Hamada AA, 2006. Evaluation of dual gold $96 \%$ EC (S-metolachlor) alone or in mixture with atrazine for preemergence weed control in sorghum. Proceedings: The $74^{\text {th }}$ meeting of the national pests and diseases committee, Wad Medani (Sudan), pp. 154-168.

Onofri A, 1996. Biological activity, field persistence and safe recropping intervals for imazethapyr and rimsulfuron on a silty-clay soil. Weed Research, 36, 73-83.

Peixoto MF and Souza IF de, 2002. Effects of imazamox and crop residues of sorghum (Sorghum bicolor Moench) on weed control in soybean (Glycine max Merr.) under no-till system. Ciência e Agrotecnologia, 26, 252-258.

Perez JP, 1986. Efecto de diferentes dosis de atrazina, 2,4-D y su mezcla en sorgo para grano (Sorghum bicolor Moench). Thesis for PhD.

Pohlan J and Salazar D, 1994. Moeglichkeiten der Integrierten Unkrautbekaempfung in Hybrid-Sorghum (Sorghum bicolor Moench) waehrend der Trocken- und Regenzeit in Nikaragua. Mitteilungen-der-Gesellschaft-für Pflanzenbauwissenschaften 7, 187-189(Ge).

Ramirez A and Socorro J, 1998. Chemical control of weeds in forage sorghum (Sorghum bicolor Moench.) within minimal tillage in the South of Sinaloa State. Thesis for PhD.

Rapparini, G. 1994. The previous weeding of maize and sorghum is still of paramount importance. Informatore Agrario, 50, 39-44.

Rapparini G, 1999. The weed control of maize and sorghum [Zea mays L. - Sorghum bicolor Moench. - Emilia-Romagna]. Informatore Agrario, 55, 65-81.

Rapparini G, 2001. Weed control of maize and sorghum [Zea mays L. - Sorghum bicolor Moench.]. Informatore Agrario, 57, 59-72.

Rapparini G, 2002. Weed control of maize and sorghum [Zea mays L. - Sorghum bicolor Moench]. Informatore Agrario, 58, 73-78, 8186, 89-91.

Rapparini G, 2003. Pre- and post-emergence weed control in maize and sorghum [Zea mays L. - Sorghum bicolor Moench - Italy] Informatore Agrario, 59, 71-74, 77-81, 84-85, 87-89.

Rapparini G, 2004. Weed control of maize and sorghum [Zea mays L.; Sorghum bicolor Moench.; Italy]. Informatore Agrario, 60, 75-88.

Rapparini G, 2005. Pre-and post-emergence weed control in maize [Zea mays L.) Sorghum bicolor Moench; Italy]. Informatore Agrario, 61,67-78.
Rapparini G, 2006. Guidelines for post-emergence weed control in maize [Zea mays L.] and sorghum [Sorghum bicolor Moench; Italy]. Informatore Agrario, 62, 67-74.

Rapparini G, Campagna G and Bartolini D, 1996. Weed control of maize and sorghum. Verification of disciplinaries of Emilia Romagna [EC 2078/92 regulation]. Informatore Agrario, 52, 71-73.

Rodella RA, 1991. Effects of herbicides on seedling anatomy of Sorghum bicolor Moench. Agro-Ciencia, 7, 11-17.

Rodríguez EB and Manzanilla E, 1986. Ensayo preliminar con protectores de semilla de sorgo (Sorghum bicolor) a la acción herbicidas grupo anilidas. 4 Jornadas Técnicas en Biología y Combate de Malezas, Maturín (Venezuela), pp. 15-17.

Rosa Santos G de la 1985. Reconocimiento de malezas tolerantes de herbicidas hormonales en el cultivo del sorgo (Sorghum bicolor Moench) en el oriente bajo del estado de Morelos. Thesis for PhD (Es).

Rosales-Robles E, 1993. Postemergence shattercane (Sorghum bicolor) control in corn (Zea mays) in Northern Tamaulipas, Mexico. Weed technology: a journal of the Weed Science Society ofAmerica, 7,830-834.

Roy C, Guggiari F and Compagnon JM, 2002. S-metolachlor, maize, sorghum and sunflower herbicide. Phytoma. La Défense des Végétaux, 548, 51-53.

Saayman J, 2002. Wild sorghum problems in cultivated sorghum. SACo-op, 18, 1-5.

Sabatka RG, Roeth FW, Martin AR and Mortensen DA, 1996. Shattercane (Sorghum bicolor) biotype variation in tolerance to primisulfuron. Weed technology: a journal of the Weed Science Society of America, 10, 363-367.

Shakoor A, Islam S and Naeem M, 2000. Efficacy of different herbicides for control of weeds in sorghum (Sorghum bicolor) under rainfed conditions. Pakistan Journal of Biological Science, 3, 463465.

Simarmata M and Penner D, 1993. Protection from primisulfuron injury to corn (Zea mays) and sorghum (Sorghum bicolor) with herbicide safeners. Weed technology: a journal of the Weed Science Society ofAmerica, v. 7, 174-179.

Snyman J, 1998. Wild sorghum: the farmer's nightmare weed. Farmer's Weekly, 1, 13-14.

Tom SE and Courtney AD, 1993. The significance of crop density on the tolerance of irrigated crops to pendimethalin in the Sudan. Proceedings of an International Crop Protection Conference, Brighton, UK, pp. 647-648.

Tsuru M, Watanabe H, Kasuga S and Momoze M, 2005. Weed control by broadcasting and dense sowing of forage sorghum (Sorghum bicolor Moench). Japanese Journal of Grassland Science, 51, 152-156.

Unger PW, 1994. Tillage effects on dry land wheat and sorghum production in the southern Great Plains. Agronomy journal, 86, 2, 310-314.

Vajs S, Leskovsek R, Miklavc J, Matko B and Lesnik M, 2007. Possibilities of chemical weed control in sorghum (Sorghum bicolor Moench) fields. $8^{\text {th }}$ Slovenian Conference on Plant Protection, Radenci(Slovenia), pp. 88-98.

Vecchiettini M, 1997. Grain sorghum cultivation [ltaly]. Terra e Vita, 38, 96-98.

Walker RH, Norris BE Jr and McGuire JA, 1991. Grass weeds management systems in grain sorghum (Sorghum bicolor). Weed technology: a journal of the Weed Science Society of America, 5, 5460.

Wicks GA, Martin DA and Mahnken GW, 1995. Cultural practices 
in wheat (Triticum aestivum), on weeds in subsequent fallow and sorghum (Sorghum bicolor). Weed science, 43, 434-444.

Wicks GA, Nordquist PT, Hanson GE and Schmidt JW, 1994. Influence of winter wheat (Triticum aestivum) cultivars on weed control in sorghum (Sorghum bicolor). Weed science, 42, 27-34.

Wicks GA, 1985. Early application of herbicides for no-till sorghum (Sorghum bicolor) in wheat (Triticum aestivum) stubble. Weed science, 33, 713-716.

Wicks GA, Martin AR, Haack AE and Mahnken GW, 1994. Control of triazine-resistant kochia (Kochia scoparia) in sorghum (Sorghum bicolor). Weed technology: a journal of the Weed Science Society of America, 8, 748-753.

Wicks GA, Smika DE and Hergert GW, 1988. Long-term effects of no-tillage in a winter wheat (Triticum aestivum) - sorghum (Sorghum bicolor) - fallow rotation. Weed science, 36, 384-393.

Wilkinson RE, Ramseur EL, Duncan RR and Shuman LM, 1990.
Relationship between metolachlor sensitivity and $\mathrm{Mn}$ toxicity tolerance in sorghum cultivars. Developments in Plant and Soil Sciences, 42, 263-268.

Wright DL, Vanderlip RL, Regehr DL, Moshier LJ and Russ OG, 1992. Grain sorghum hybrid response to Lasso and Dual herbicides and efficacy of Screen, Concep III and Concep III/Apron seed safeness. Bulletin - Kansas Agricultural Experiment Station, 659, 2830.

Zama P and Hatzios KK, 1986. Effects of CGA-92194 on the chemical reactivity of metolachlor with glutathione and metabolism of metolachlor in grain sorghum (Sorghum bicolor). Weed science, 34, 834-841.

Zhang Z, Coats GE and Boyd AH, 1994. Germination and seedling growth of sorghum (Sorghum bicolor) hybrids after seed storage with safeness at varying humilities. Weed science, 42, 98-102. 
Reviews

Problems and achievements of cotton (Gossypium Hirsutum L.) weeds control

T. Barakova, G. Delchev

Achievements and problems in the weed control in grain sorghum (Sorghum Bicolor Moench.)

G. Delchev, M. Georgiev

\section{Genetics and Breeding}

Parthenogenetic responsiveness of sunflower hybrid combinations with expressed tolerance to herbicides

M. Drumeva, P. Yankov

In vitro propagation of oil-bearing rose (Rosa damascena Mill.)

V. Badzhelova

\section{Nutrition and Physiology}

Variation in the chemical composition and physical characteristics of grain from winter barley varieties

B. Dyulgerova, N. Dyulgerov, D. Dimova

Haematological and serum biochemical indices of broiler chickens fed raw sickle pod (Senna obtusifolia) seed meal

C. Augustine, I.D. Kwari, J.U. Igwebuike, S.B. Adamu

Prey size selectivity of pikeperch (Sander Lucioperca L.) fed with topmouth gudgeon (Pseudorasbora Parva Temminck \& Schlegel)

M. Gevezova-Kazakova, M. Yankova, T. Hubenova, A. Zaikov, G. Rusenov

Influence of organic nitrogen amendment, containing amino acids on the cellulase and xylanase, produced by Trichoderma spp. isolates

D. Draganova, I. Valcheva, Y. Kuzmanova, M. Naydenov

\section{Production Systems}

Justification of a method for determining the moment for switching on the level one signaling of filled grain harvester hoppers

G. Tihanov, B. Kolev, K. Trendafilov, N. Delchev, Y. Stoyanov

Mathematical approaches for assessment and classification of the European Union member states based on the average yield of vegetables for the period 1961-2014

N. Keranova 
Present status of Zymoseptoria tritici (Mycospharella graminicola /Fuckel/ Schroter) of the wheat cultures in the Republic of Macedonia

I. Karov, E. Arsov

\section{Agriculture and Environment}

Influence of basic agrotechnical activities on the productivity and yield of Triticum monococcum $\mathrm{L}$.

S. Stamatov, K. Uzundzhalieva, E. Valchinova, G. Desheva, P. Chavdarov, B. Kyosev, T. Cholakov, R.

Ruseva, N. Velcheva

Avifauna abundance and diversity in Jos wildlife park, Nigeria

B.T. Kwaga, D. lliya, A. Ali, D. Khobe

Ecological analysis of the flora in the 'Chinarite' protected area - Rodopi municipality, Bulgaria

L. Dospatliev, M. Lacheva

Product Quality and Safety

Food emulsions with amidated pectin from celery (Apium graveolens var. rapaceum D. C.) tubers Iv. Petrova, N. Petkova, M. Ognyanov, Ap. Simitchiev, M. Todorova, P. Denev

M. Tonchev, T. Atanasov, A. Todorova, Ts. Atanasova, N. Shtrankova, M. Momchilova G. Zsivanovits

\section{Short Communication}

Influence of elevated platform (wire-mesh or wooden) in the cage on domestic rabbit (Oryctolagus cuniculus) activity

S. Peeva, E. Raichev, D. Georgiev, A. Stefanov 


\section{Instruction for authors}

\section{Preparation of papers}

Papers shall be submitted at the editorial office typed on standard typing pages (A4, 30 lines per page, 62 characters per line). The editors recommend up to 15 pages for full research paper ( including abstract references, tables, figures and other appendices)

The manuscript should be structured as follows: Title, Names of authors and affiliation address, Abstract, List of keywords, Introduction, Material and methods, Results, Discussion, Conclusion, Acknowledgements (if any), References, Tables, Figures.

The title needs to be as concise and informative about the nature of research. It should be written with small letter /bold, 14/ without any abbreviations.

Names and affiliation of authors The names of the authors should be presented from the initials of first names followed by the family names. The complete address and name of the institution should be stated next. The affiliation of authors are designated by different signs. For the author who is going to be corresponding by the editorial board and readers, an E-mail address and telephone number should be presented as footnote on the first page. Corresponding author is indicated with *

Abstract should be not more than 350 words. It should be clearly stated what new findings have been made in the course of research. Abbreviations and references to authors are inadmissible in the summary. It should be understandable without having read the paper and should be in one paragraph.

Keywords: Up to maximum of 5 keywords should be selected not repeating the title but giving the essence of study.

The introduction must answer the following questions: What is known and what is new on the studied issue? What necessitated the research problem, described in the paper? What is your hypothesis and goal?

Material and methods: The objects of research, organization of experiments, chemical analyses, statistical and other methods and conditions applied for the experiments should be described in detail. A criterion of sufficient information is to be possible for others to repeat the experiment in order to verify results.

Results are presented in understandable tables and figures, accompanied by the statistical parameters needed for the evaluation. Data from tables and figures should not be repeated in the text. Tables should be as simple and as few as possible. Each table should have its own explanatory title and to be typed on a separate page. They should be outside the main body of the text and an indication should be given where it should be inserted.

Figures should be sharp with good contrast and rendition. Graphic materials should be preferred. Photographs to be appropriate for printing. Illustrations are supplied in colour as an exception after special agreement with the editorial board and possible payment of extra costs. The figures are to be each in a single file and their location should be given within the text.

Discussion: The objective of this section is to indicate the scientific significance of the study. By comparing the results and conclusions of other scientists the contribution of the study for expanding or modifying existing knowledge is pointed out clearly and convincingly to the reader. Conclusion: The most important consequences for the science and practice resulting from the conducted research should be summarized in a few sentences. The conclusions shouldn't be numbered and no new paragraphs be used. Contributions are the core of conclusions. References:

In the text, references should be cited as follows: single author: Sandberg (2002); two authors: Andersson and Georges (2004); more than two authors: Andersson et al.(2003). When several references are cited simultaneously, they should be ranked by chronological order e.g.: (Sandberg, 2002; Andersson et al., 2003; Andersson and Georges, 2004).

References are arranged alphabetically by the name of the first author. If an author is cited more than once, first his individual publications are given ranked by year, then come publications with one co-author, two co-authors, etc. The names of authors, article and journal titles in the Cyrillic or alphabet different from Latin, should be transliterated into Latin and article titles should be translated into English. The original language of articles and books translated into English is indicated in parenthesis after the bibliographic reference $($ Bulgarian $=\mathrm{Bg}$, Russian $=\mathrm{Ru}$, Serbian $=\mathrm{Sr}$, if in the Cyrillic, Mongolian =
Mo, Greek = Gr, Georgian = Geor., Japanese $=\mathrm{Ja}$, Chinese $=\mathrm{Ch}$, Arabic $=\mathrm{Ar}$, etc.)

The following order in the reference list is recommended:

Journal articles: Author(s) surname and initials, year. Title. Full title of the journal, volume, pages. Example:

Simm G, Lewis RM, Grundy B and Dingwall WS, 2002. Responses to selection for lean growth in sheep. Animal Science, 74, 39-50

Books: Author(s) surname and initials, year. Title. Edition, name of publisher, place of publication. Example:

Oldenbroek JK, 1999. Genebanks and the conservation of farm animal genetic resources, Second edition. DLO Institute for Animal Science and Health, Netherlands.

Book chapter or conference proceedings: Author(s) surname and initials, year. Title. In: Title of the book or of the proceedings followed by the editor(s), volume, pages. Name of publisher, place of publication. Example:

Mauff G, Pulverer G, Operkuch W, Hummel K and Hidden C, 1995. C3variants and diverse phenotypes of unconverted and converted C3. In: Provides of the Biological Fluids (ed. $\mathrm{H}$. Peters), vol. 22, 143-165, Pergamon Press. Oxford, UK.

Todorov N and Mitev J, 1995. Effect of level of feeding during dry period, and body condition score on reproductive performance in dairy cows, IX $X^{\text {th }}$ International Conference on Production Diseases in Farm Animals, September 11-14, Berlin, Germany.

Thesis:

Hristova D, 2013. Investigation on genetic diversity in local sheep breeds using DNA markers. Thesis for PhD, Trakia University, Stara Zagora, Bulgaria, (Bg).

The Editorial Board of the Journal is not responsible for incorrect quotes of reference sources and the relevant violations of copyrights.

\section{Animal welfare}

Studies performed on experimental animals should be carried out according to internationally recognized guidelines for animal welfare. That should be clearly described in the respective section "Material and methods". 


\section{AGRICULTURAL \\ SCIENCE AND TECHNOLOGY}

Volume 9, Number 3

September 2017
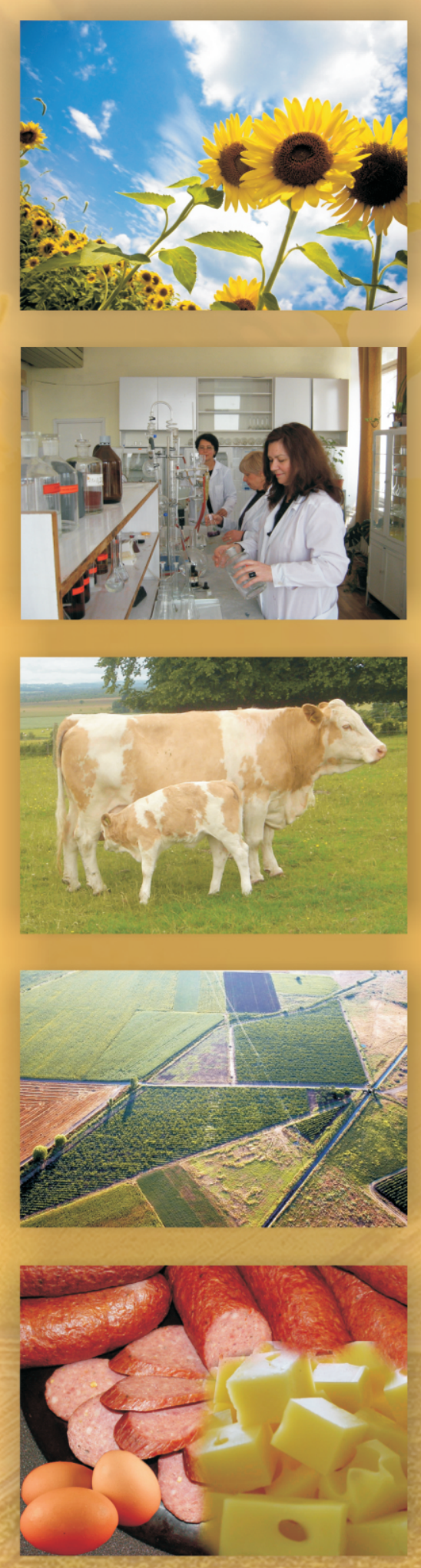

Journal web site: 